\title{
AN INTERNATIONAL APPROACH OF THE RELATIONSHIP BETWEEN BOARD ATTRIBUTES AND THE DISCLOSURE OF CORPORATE SOCIAL RESPONSIBILITY ISSUES
}

\author{
María Consuelo Pucheta-Martínez \\ Associate Professor \\ Universidad Jaume I \\ Departamento de Finanzas y Contabilidad \\ Campus del Riu Sec, s/n \\ 12071-Castellón \\ Spain \\ Phone: 0034964387141 \\ e-mail:pucheta@cofin.uji.es \\ Isabel Gallego-Álvarez \\ Associate Professor \\ University of Salamanca \\ Multidisciplinary Institute for Enterprise (IME) \\ Department of Business Administration \\ Campus Miguel de Unamuno, Edificio FES \\ 37007-Salamanca \\ Spain \\ e-mail: igallego@usal.es
}




\title{
AN INTERNATIONAL APPROACH OF THE RELATIONSHIP BETWEEN BOARD ATTRIBUTES AND THE DISCLOSURE OF CORPORATE SOCIAL RESPONSIBILITY ISSUES
}

\begin{abstract}
Firms interested in being perceived by all stakeholders and society as drivers of CSR activities, especially regarding CSR reporting, should have boards of directors that defend not only shareholder interests, but also all stakeholders' needs. Thus, we expect that efficient boards, particularly if well-structured, will impact on CSR disclosure. As a result, in this paper, we examine the effect of board composition, particularly board size, board independence, board gender diversity, CEO duality and CSR board committee, on CSR reporting. Using a sample of international firms, concretely 13,178 observations belonging to 39 countries, we hypothesize that all these attributes positively affect CSR disclosure, except board independence and CEO duality, which are expected to impact negatively. These hypotheses are theoretically supported by the agency and stakeholder perspectives. Our findings support all the hypotheses, except that of CEO duality, and, therefore, we conclude that board characteristics such as board size, board gender diversity and CSR board committees encourage the disclosure of CSR matters, while board independence discourages this reporting. Contrary to our predictions, CEO duality has a positive effect on CSR reporting. This paper offers empirical evidence for the agency and stakeholders approaches at the international level for the board attributes that contribute to a better CSR disclosure. In this regard, our evidence suggests that more investigation on other human capital's characteristics of independent directors such as expertise or background need to be addressed.
\end{abstract}

Key words: Board size, board independence, board gender diversity, CEO duality, CSR board committee, CSR reporting, international perspective. 


\section{AN INTERNATIONAL APPROACH OF THE RELATIONSHIP BETWEEN BOARD ATTRIBUTES AND THE DISCLOSURE OF CORPORATE SOCIAL RESPONSIBILITY ISSUES}

\section{Introduction}

Within the context of organizational governance, the disclosure of corporate social responsibility (CSR) information allows firms to maintain close relations with all stakeholders and to be perceived by society as actors committed to CSR matters (e.g., Simpson and Kohers, 2002). In this way, firms can signal to society that they are interested in meeting the expectations and needs of shareholders and all stakeholders (Arvidsson, 2010), because the disclosure of social and environmental issues may be useful for decreasing agency problems and information costs in capital markets, enhancing companies' reputation and increasing stock values, among others (Jensen and Meckling, 1976; Jizi, 2017).

Decisions such as allocating resources to companies, CSR commitment to stakeholders and society, maintaining a company's relations with all stakeholders and CSR strategic actions, among others, are made by boards of directors. These decisions may result in a more sustainable business. Therefore, as Gray, Kouhy and Lavers (1995) suggest, efficient boards will be likely to support CSR reporting when it is in the company's interest to signal to all stakeholders and society that they are committed to their needs. In addition, societal pressure also may drive boards to engage with all stakeholders and, consequently, boards may encourage the reporting of CSR issues.

Hence, boards of directors can play a relevant role in enhancing the transparency of firms by increasing the voluntary reporting of CSR information. According to prior research, the efficiency of boards in encouraging CSR reporting, in maintaining good relations with all stakeholders, in creating firm performance and in satisfying all stakeholders' needs, among others, depends on their composition (e.g., De-Mandojana and Aragon-Correa, 2015). In this regard, Jamali, Safieddine, and Rabbath (2008) support the idea that board structure is a key element in organizational decision making regarding CSR disclosure. The composition of boards is chosen mainly to defend shareholders' interests, but it is also assumed that efficient boards will satisfy and attend to all stakeholders' needs (e.g., Guest, 2009).

There is a good amount of previous research that examines corporate governance and CSR reporting in a separate way, but empirical evidence is scarce when we focus on the effect of corporate governance mechanisms such as boards of directors, particularly their composition, and CSR disclosure (e.g., Chan, Watson, and Woodliff, 2014; Jain and Jamali, 
2016). Thus, in this analysis we examine how board structure, particularly board size, board independence, board gender diversity, CEO duality and CSR board committee impact CSR reporting in a sample of international companies.

Our paper shows that certain board attributes affect CSR reporting. Concretely, we find that board size, board gender diversity and CSR board committees have a positive effect on CSR disclosure, while board independence is negatively associated with CSR reporting. CEO duality shows a positive association with CSR disclosure, contrary to our expectations. Accordingly, this paper contributes to previous empirical literature in several ways. First, our results find that most board characteristics positively influence the disclosure of CSR matters, but others do so negatively and, therefore, firms should make up their boards with the appropriate attributes in order to be active in reporting CSR issues. If companies are interested in signaling to society that they are involved with CSR activities, the composition of their boards should be characterized by a large size, heterogeneity in gender, with CEO duality and a CSR committee. In contrast, having more independent directors on boards discourages the reporting of CSR matters. Thus, firms must think about the inclusion of independent directors on boards if they want to be perceived by society as a driver of CSR matters. In this case, it would be recommendable to consider a low presence of independent directors on boards. Secondly, we evidence that board composition, particularly certain characteristics, can be a relevant corporate governance mechanism that drives firms to engage with shareholders and all stakeholders in terms of enhancing transparency with the reporting of CSR information. Finally, our findings also reinforce the thesis that female directors on boards result in firms with a greater social and environmental commitment. Female leadership style differs from that of men, and women directors tend to be more ethical, more sensitive to social and environmental matters and more democratic, among other things, and, consequently, they are more likely to support policies to disclose CSR information. Thus, board gender diversity also becomes an important firm governance driver encouraging the disclosure of CSR issues.

The paper is structured as follows. Following this introduction, the theoretical background and hypotheses are provided. In the third section, we present the empirical design, where the sample and variables are described. In the fourth section, the findings are analyzed and in the last section, we draw the conclusions and implications derived from our analysis. 


\section{Theoretical background and hypotheses}

Agency perspective is the most prominent theory used to examine the association between corporate governance, such as board attributes, and CSR reporting (e.g., Jain and Jamali, 2016; Sundarasen, Je-Yen, and Rajangam, 2016). The relationship between shareholders and managers triggers agency problems due to the information asymmetries between them (Jensen and Meckling, 1976). Therefore, the board of directors becomes a corporate governance mechanism for shareholders to mitigate agency costs and to align management and shareholder interests, but boards also take into account all stakeholder interests affected by management decisions (Jain and Jamali, 2016). Jamali et al. (2008) also show that the board of directors is a relevant tool for supporting CSR matters. Bear, Rahman, and Post (2010, p. 209) state that "in order to exercise its monitoring function the board needs the appropriate mix of experience and capabilities to evaluate management and assess business strategies and their impact on CSR". Thus, some board attributes may promote CSR disclosure (Rao and Tilt, 2016) as a way of reducing information asymmetry and, consequently, decreasing agency costs.

In this regard, some prior research (e.g., Chen and Jaggi, 2001; Said, Zainuddin, and Haron, 2009; Khan, 2010; Fernandez-Feijoo, Romero, and Ruiz, 2012; Rao, Tilt, and Lester, 2012; Jizi, Salama, Dixon, and Stratling, 2014) shows that board independence, board diversity (including board gender diversity), CEO duality, board size and board committees such as audit committees, among others, positively affect financial, CSR and environmental disclosure. On the other hand, Eng and Mark (2003) and Huafang and Jianguo (2007), for instance, find that board independence and CEO duality have a negative effect on nonmandatory reporting, respectively. Hence, although the evidence regarding the relationship between board characteristics and CSR matters is mixed, most prior evidence seems predominantly to report a positive association between them (Rao and Tilt, 2016).

Additionally, the stakeholder approach is one of the most prominent theories used by researchers for examining the relationship between corporate governance and corporate disclosure (e.g., Huang and Kung, 2010; Montiel and Delgado-Ceballos, 2014). The stakeholder perspective extends the agency perspective since stakeholder theory argues that the board of directors not only preserves the interests of shareholders, but also the interests of all stakeholders (Freeman, 1984). The relations between firms and stakeholders legitimize the latter to be considered in the decision-making process of firms and, as a result, boards should represent several stakeholders' interests. The management team may not be interested in CSR issues owing to personal benefits and interests, and this type of behavior is in detriment to 
shareholders and all stakeholders. Thus, stakeholder theory posits that the boards of directors are effective monitoring mechanisms for protecting all stakeholders' interests and, therefore, they will be effective in getting the management team involved with CSR matters.

In this regard, stakeholders will expect companies to report on CSR issues in order to reduce information asymmetries and in order to evaluate the firm's engagement with CSR matters. According to Brammer, Millington, and Pavelin (2007), if stakeholders perceive that companies are not engaged with CSR issues, they may pressure them to disclose CSR information. Additionally, by reporting CSR matters, firms may garner a better reputation and identity (Hooghiemstra, 2000; Chan, Watson, and Woodliff, 2014). Thus, boards of directors, particularly their attributes, will be key to pressuring the management team to disclose CSR matters. In this way, boards can allow companies to behave in a way that satisfies all stakeholders' interests (e.g., De Graaf and Stoelhorst, 2009).

Therefore, in what follows we analyze the relationship between certain board attributes, concretely board size, board independence, board gender diversity, CEO duality and CSR board committee and CSR reporting, drawing on agency and stakeholder theories.

\section{Board size}

Corporate disclosure is a strategic decision to be considered by the board. The monitoring, controlling and reporting of companies are affected by board size. According to group dynamics, boards with few members will be more efficient and effective at supervising and monitoring managers than boards with more members. Small boards will result in better coordination and communication between directors and a higher accountability and engagement of all board directors as individuals (Dey, 2008). Nevertheless, John and Senbet (1998) argue that small boards also have shortcomings, since individual directors will have more tasks and responsibilities and, therefore, the controlling and supervising role and ability of board directors may be restricted. Furthermore, as Guest (2009) suggests, boards with few members may lack diverse expertise, which would negatively affect the controlling and advisory roles of the board. Given that CSR disclosure requires a workload, it is expected that this question will be considered on boards.

Large boards may benefit firms in several ways, such as providing increases in firm value (Kalsie and Shrivastav, 2016) or a higher quality of financial reporting (Obigbemi, Omolehinwa, Mukoro, Ben-Caleb, and Olusanmi, 2016), among others. Thus, one of the attributes that makes boards effective in the sense of pressuring the management team to disclose CSR issues is their size (Jizi et al., 2014). This idea is supported by the stakeholder 
perspective, which posits that big boards not only represent the shareholders' interests, but also the interests of the rest of the stakeholders. Thus, the pressure of diverse sensibilities represented on boards may force managers to report CSR information. Dalton, Daily, Johnson, and Ellstrand (1999) also support the thesis that big boards are more likely to have directors with different kinds of experience and capabilities, which will be helpful for solving conflicts and making decisions, such as disclosing CSR matters.

Cormier, Ledoux, Magnan, and Aerts (2010) show that board size enhances corporate governance reporting, mitigating information asymmetry and, consequently, agency costs. This finding suggests that board size is an attribute that contributes to voluntarily disclosing information such as CSR, reducing agency problems between shareholders and managers and aligning their interests.

Although there is mixed evidence as to the association between board size and CSR disclosure, most of previous research shows a positive relationship. In this regard, authors such as Brown, Helland, and Smith (2006), Frías-Aceituno, Rodríguez-Ariza, and GarcíaSánchez (2013), Ntim and Soobaroyen (2013), Jizi et al. (2014), García-Meca and PuchetaMartínez (2017) and Jizi (2017) find that large boards positively influence CSR reporting.

Based on above arguments, we posit the following hypothesis:

$H_{1}$ : Board size of firms is positively associated with CSR reporting

\section{Board independence}

Board independence is another board attribute that has an impact on CSR disclosure. Board independence is a relevant corporate governance mechanism for controlling and monitoring the management team and for safeguarding shareholders' interests, particularly minority shareholders' interests (Agrawal and Knoeber, 1996). Additionally, RodríguezAriza, Frías-Aceituno, and García-Rubio (2014) argue that independent directors will be expected to make decisions to ensure that firms achieve their aims and behave adequately from an independent, external and objective perspective, which will result in a higher quantity and quality of information disclosure. In this regard, prior research (e.g., Cheng and Courtenay, 2006; Prado-Lorenzo, Gallego-Alvarez, and Garcia-Sanchez, 2009) finds a positive relationship between board independence and voluntary disclosure.

However, independent board members are mainly appointed for their financial expertise, according to Fligstein (1991), as well as for their professional background and good reputation, among other things, and do not have any commercial or investment relation with the firm and its shareholders. Their financial knowledge allows them to assess financial 
information better than other kinds of information such as CSR. Keasey and Hudson (2002) argue that independent directors can assess managers' actions and detect and solve problems arising from managers' behavior should they have industry knowledge of firms and the appropriate expertise, and Reeb and Zhao (2013) show that an effective reporting quality depends on whether the independent directors meet the aforesaid capabilities. Additionally, these directors may be dominated by CEOs and their role in monitoring the management team and obtaining external resources might be put at risk (Johnson, Schnatterly, and Hill, 2012). In this case, independent directors might discourage companies from voluntarily reporting information on matters such as CSR. Authors such as Eng and Mak (2003), Haniffa and Cooke (2005), Lim, Matolcsy, and Chow (2007), Prado-Lorenzo and Garcia-Sanchez (2010) and Arora and Dharwadkar (2011), among others, find that board independence has a negative effect on voluntary disclosures, including CSR disclosure.

Therefore, based on above arguments, we predict that board independence negatively affects CSR reporting. Prado-Lorenzo and Garcia-Sanchez (2010) demonstrate that the disclosure of CSR issues such as greenhouse gases emissions may benefit all stakeholders, but can be contrary to shareholders' interests. Thus, independent directors will be less likely to support the reporting of CSR matters in order to protect the interests of shareholders. In this sense, we posit the following hypothesis:

\section{$\mathrm{H}_{2}$ : Board independence of firms is negatively associated with CSR reporting}

\section{Board gender diversity}

Board gender diversity has received growing attention within corporate governance (Carrasco and Laffarga, 2007). Research suggests that female directors play a relevant role in enhancing board effectiveness and shows the positive impact of board gender diversity on improving the quality of financial information and fostering good corporate practices, among other things (Pucheta-Martínez, Bel-Oms, and Olcina-Sempere, 2016; Rogelberg and Rumery, 1996).

Agency theory argues that a female leadership style might foster the disclosure of CSR issues and, consequently, female directors may be good drivers of CSR matters. In this regard, male and female leadership styles are different since women leaders are more sensitive, sympathetic and caring than men directors, implying that women directors tend to be more likely to cooperate (Kim, 2013). Bird and Brush (2002), Davis, Capobianco, and Kraus (2010) and Melero (2011) propose that female directors are more democratic than males in the decision-making process, their orientation towards interpersonal relations is higher and they 
are able to motivate a company's employees better. Evidence provided by Nielsen and Huse (2010) and Matsa and Miller (2013), among others, suggests that women leaders are more attentive and sensitive to stakeholders' demands, especially to social and environmental matters, showing more effective leadership in the corporate environment. In this sense, according to Evans (2010), communication, multi-tasking and active listening are relevant abilities of female directors, allowing them to bring together shareholders in the decisionmaking process.

Psychological, sociological and cognitive perspectives posit that women directors affect corporate governance and significant firm decisions. Prior research (e.g., Levi, Li, and Zhang, 2014; Man and Wong, 2013) finds that women directors are more adverse towards risk, more conservative and more prudent than men directors when making important decisions. These qualities show that female directors have more social and ethical abilities than male directors and behave in a more responsible way and, therefore, will be able to align both managers' and shareholders' interests and make relevant firm decisions, such as disclosing CSR issues.

Drawing on the stakeholder approach, society may perceive that firms are engaging with CSR matters when they include women directors on boards, which also signals to society that firms are oriented towards stakeholders (e.g., Ibrahim and Angelidis, 1994). Furthermore, this perspective also argues that women directors on boards may encourage CSR reporting because they are more-open minded than men, ensuring the support of stakeholders' interests, and because they are more capable of taking steps to get firms to become more environmental and socially engaged and also more democratic (Hillman, Cannella, and Harris, 2002; Larrieta-Rubín de Celis, Velasco-Balmaseda, Fernández de Bobadilla, Alonso-Almeida, and Intxaurburu-Clemente, 2015). In this regard, Rao et al. (2012) evidence that heterogeneous boards encourage CSR reporting. Similar findings are reported by authors such as Barako and Brown (2008), Fernandez-Feijoo, Romero, and Ruiz-Blanco (2012, 2014), Ntim and Soobaroyen (2013), Lone, Ali, and Khan (2016) and Tamini and Sebastianelli (2017), among others, who find a positive association between board gender diversity and CSR, or environmental, social and governance disclosure.

According to above arguments, female directors' more social and environmentally oriented attitude and sensitivity, as well as other characteristics of their leadership style, may mean that they are more likely to influence other directors to become more engaged with social and environmental matters, thus increasing the reporting of CSR information. Accordingly, we posit the following hypothesis: 


\section{$H_{3}$ : Board gender diversity of firms is positively associated with CSR reporting}

\section{CEO duality}

CEO duality refers to the situation when the CEO (management) also holds the position of chairman (control) of the board of directors, such that CEO duality results in an intensification of managerial power (Rechner and Dalton, 1991; Surroca and Tribo, 2008).

The effect of CEO duality on CSR disclosure has been examined in past research, providing contradictory findings. Consistent with agency theory, it is likely that managers' personal interests will affect their commitment to CSR practices and disclosure. Thus, the managerial power of CEO duality may encourage the management team to re-evaluate CSR activities, if it perceives that they are not valuable. In this regard, CEO duality might mitigate the effectiveness of the monitoring role of directors, may restrict the transparency to shareholders and all stakeholders (e.g., Giannarakis, 2014; Sundarasen et al., 2016) and may constrain the execution of certain governance roles, such as CSR disclosure. Inside directors may be influenced by a CEO-chairman, supporting decisions against shareholders' interests, because insiders do not wish to confront the CEO-chairman. For this reason, CEO duality might have a negative effect on CSR reporting since managers, including the CEO, may use CSR activities to their own benefit and contrary to shareholders' and stakeholders' needs and interests. Authors such as Chau and Gray (2010) and Donnelly and Mulcahy (2008) show the negative impact of a Chair-CEO figure on a company's transparency since it decreases voluntary disclosures, including CSR information.

Conversely, CEO duality, as Finkelstein and D'Aveni (1994) argue, may also be effective by playing an important supervising role. When CEOs also hold the position of chair of the board they might be interested in encouraging CSR reporting since it signals to society and stakeholders their engagement with CSR issues. As a consequence, the CEOs' reputation, tenure and legitimation by society may improve as well as they become more successful and might be rewarded through higher compensation. Along this line, Jiraporn and Chintrakarn (2013) argue that when CEO duality exists, CEOs use CSR disclosure as an opportunistic instrument to enhance their reputation. Additionally, CEOs may support CSR reporting because it may help them avoid the pressure of dominant stakeholders and may decrease monitoring by boards, capital markets or legislators (Jizi et al., 2014). Prior research (Jiraporn and Chintrakarn, 2013; Mallin, Michelon, and Raggi, 2013; Jizi et al., 2014) reports the positive association between CEO duality and CSR reporting, which supports the idea that CEO duality is not always harmful. Tamini and Sebastianelli (2017) also find that CEO 
duality on boards increases the disclosure of more environmental-social-governance information and, therefore, this results in firms being more transparent. Additionally, Pathan (2009) and Barry, Lepetit, and Tarazi (2011) suggest that when CEOs also hold the position of chair of the board, this situation may positively affect the disclosure of CSR matters, which would be carried out to defend human capital that may be threatened by investors interested in gaining profitability in the short term, and in order to handle risk not only with financial and investment strategies, but also with CSR strategies.

Based on above perspectives, although the evidence on the association between CEO duality and CSR disclosure is mixed, most of prior research supports a negative effect of CEO duality on CSR reporting. Accordingly, we posit the following hypothesis:

$\mathrm{H}_{4}$ : $\mathrm{CEO}$ duality on boards is negatively associated with CSR reporting

\section{CSR board committee}

Board committees such as CSR committees have become an important matter within corporate governance and the CSR field since they may enhance CSR policies. Through CSR board committees, firms signal their concerns with their environmental and social reputation and, consequently, setting up CSR committees with board directors should result in more engagement in providing an improved CSR quality (Wahyuni, Rankin, and Windsor, 2009; Adnan, Staden, and Hay, 2010). Drawing on the stakeholder approach, it can be said that companies that create CSR board committees are supporting boards interested in satisfying stakeholder's needs and interests concerning the socially responsible behavior of firms and are providing guarantees to shareholders and all stakeholders on accountability issues (Dias, Rodrigues and Craig, 2017).

CSR committees are expected to be comprised of experts in CSR issues and, therefore, their directors may better supervise all matters relative to CSR practices. Efficient CSR committees will be expected to increase company transparency by disclosing CSR information. Thus, they show more engagement and more accountability with CSR strategies and policies.

Vigneau, Humphreys, and Moon (2015) and Fuente, García-Sánchez, and Lozano (2017) find that the most important purpose of CSR board committees is to report CSR information, since greater transparency is a significant attribute. Consistent with this idea, Arena, Bozzolan, and Michelon (2015) suggest that boards with CSR committees are relevant corporate governance mechanisms in companies because they perform an important role in providing a better environmental performance for all stakeholders. Hence, in line with 
Michelon and Parbonetti (2012), the quantity and quality of CSR reporting is positively affected by CSR board committees.

Furthermore, Kent and Monem (2008) demonstrate that an environmental or sustainable development committee such as CSR committee improves Triple Bottom Line (TBL) reporting. Fuente et al. (2017) provide evidence that CSR board committees are positively associated with a higher company transparency concerning sustainability and Konadu (2017) shows that the presence of a CSR committee on the board increases the voluntary disclosure of environmental information.

According to the above arguments, we propose the following hypothesis:

$H_{5}$ : A CSR board committee of firm's boards is positively associated with CSR reporting

\section{Research design}

\subsection{Sample description}

The sample for the panel data analysis was taken from an initial population of 16,696 observations for the period 2004-2015. Then, following the work of La Porta, Lopez-deSilane, Shleifer, and Vishny (2000), financial companies were excluded due to the different ownership characteristics, which means they are not comparable to other firms. Financial companies carry out particular accounting practices that make it more difficult to compare their financial statements with those of companies in other business activities, since they are not homogeneous. Therefore, the final sample consists of a total of 13,178 observations belonging to 39 countries obtained from the Thomson Reuters Eikon database, which contains both economic-financial and corporate social responsibility information, although it is an unbalanced panel data sample of companies. Arellano (2003) argues that the results obtained with these panels are as reliable as those obtained with balanced panels.

Table 1 shows the frequencies by country in order to show their representativeness. Table 2 shows the sectors of activity to which the companies in the sample belong, following the TRBC economic sector classification given by Thomson Reuters and comprising 9 activity sectors. It is a market-based sectorial classification system similar to that established by the Global Industry Classification Standard (GICS).

\section{INSERT TABLE 1 HERE}

Table 1 shows that the country with the most observations in the sample is the United States (with 3,625), followed by Japan with 1,789. In contrast, other countries, such as the Isle of Man or Macau, are less represented. With respect to sector of activity, according to Table 
2, Industrials stands out with 2,816 observations, followed by Consumer cyclical with 2,484 and Telecommunications Services being the least represented sector with 521 of the total observations in the sample.

\section{INSERT TABLE 2 HERE}

\subsection{Dependent variable}

The dependent variable in the present research is CSR, which is measured using a multidimensional construct to address all the actions carried out by the different organizations, especially in the social and environmental fields (Carroll, 1979, Lee, Kim, Lee, and Li, 2012; Rupp, and Mallory, 2015). Specifically, we use the information available in the Thomson Reuters Eikon database to measure CSR by preparing an index obtained by the unweighted sum of various environmental and social items, assigning value 1 when the company does present information on that social or environmental aspect and 0 , otherwise (Kolk and Pinkse 2010, Chen and Bouvain 2009, Du, Bhattacharya, and Sen, 2010, GallegoÁlvarez and Ortas, 2017). Table 3 shows the 112 items that represent the environmental and social aspects of CSR.

\section{INSERT TABLE 3 HERE}

To obtain the multidimensional CSR construct, several areas were analyzed, such as environmental aspects, human rights and product liability. Within the environmental information presented by the companies, three major areas stand out: resource use, emissions and innovation. The use of resources reflects the performance and capacity of a company to reduce the use of materials, energy or water and that tries to find more efficient solutions to improve the management of the supply chain. The emissions category refers to the commitment and effectiveness of a company in reducing environmental emissions in production and operational processes. For its part, the innovation index reflects the capacity of a company to reduce the costs and environmental burdens of its customers, thus creating new market opportunities through new technologies and environmental processes or ecological products. Environmental aspects including many of the actions taken to protect the natural environment have also been considered in previous works (Liu 2010, Leire and Mont 2010).

The social aspects are represented in four major areas: workforce, human rights, community and product responsibility. Workforce measures the effectiveness of a company in achieving worker satisfaction, a healthy and safe workplace, maintaining diversity and equal opportunities. Human rights measures the effectiveness of a company in respecting fundamental human rights conventions, while Community focuses on the company's 
commitment to being a good citizen, protecting public health and respecting business ethics. Product responsibility reflects the ability of a company to produce quality goods and services that integrate health and safety, integrity and privacy regarding customer data. All of this is intended to support equal opportunities and diversity, health and safety systems in the work procedures implemented, support for employee training and development, customer relations and supplier relations and the level of commitment to community or social projects (Tagesson, Blank, Broberg, and Collin, 2009; Young and Marais, 2012).

\subsection{Independent variables}

To analyze how the characteristics and composition of the board of directors affect the environmental and social aspects of CSR presented by international companies, we use several independent variables.

One of the key aspects of corporate governance related to the board of directors is its size, which is usually measured considering the number of directors on the board (Kiel and Nicholson, 2003, Nakano and Nguyen, 2012). The number of directors must represent the interests of the organization and not of individual shareholders or interest groups. The size of the board of directors is one of the variables that positively influence CSR (Jizi, 2017; Jamali et al., 2008). The variable regarding the size of the board is defined as BODSIZE.

The independence of the board of directors is another of the variables that we consider in the research. When speaking of independent directors, we are referring to the existence of non-executive directors who are professionals and are totally foreign to the inner workings of the organization and, therefore, the organization will not be able to interfere with their opinions (Wan-Hussin, 2009). These directors have as their main objective to preserve a good image vis-à-vis the outside, so they should be more interested in showing the socially responsible behavior of the company (Zahra and Stanton, 1988, Arora and Dharwadkar, 2011). With respect to this variable, there is no consensus in the previous literature about how it influences the CSR information that companies disclose. While for some authors there is a positive relationship (Chen and Jaggi, 2000; Cheng and Courtenay, 2006), for others there is a negative relationship (Haniffa and Cooke, 2005; Lim, Matolcsy, and Chow, 2007; PradoLorenzo and García -Sánchez, 2010). The variable that we will use to define an independent board will be INBODMEMBERS.

Board diversity can improve business creativity and innovation, because different opinions and points of view are considered. Creativity and business innovation can improve because different opinions and points of view are considered (Brammer, Millington, and 
Pavelin, 2007). In the case of gender, women play an important role and are considered to have great abilities to communicate, cooperate and care about the ideas and opinions of others (Eagly and Johannesen-Schmidt, 2001). From this point of view, women who participate on boards of directors are considered to be more sensitive to social and environmental issues (Ibrahim and Angelidis, 1994; Marx, 2000) and may influence other members to be more socially responsible (Prado-Lorenzo and García-Sánchez, 2010; Ibrahim and Angelidis, 1994). Like size, this is one of the variables that in previous research has shown a positive relation with social and environmental practices carried out by companies (Barako and Brown, 2008, Liao, Luo, and Tang, 2015). The variable that we will use to define female participation on the board of directors will be FMLEBOARD.

CEO duality occurs when the positions of chairman of the board of directors and the chief executive of the company fall on the same person. This situation may lead to the development of strategies that favor the personal interests of the chief executive to the detriment of business interests. Therefore, some authors recommend that a separation of functions is more suitable, that is, that the position of chairman of the board of directors should not be occupied by the company's chief executive (Carter, Simkins, and Simpson, 2003; Rechner and Dalton, 1991). Regarding the results obtained in relation to CSR, they are contradictory. Some authors (Chau and Gray, 2010; Donnelly and Mulcahy, 2008) consider the existence of a negative relationship, while others estimate a positive relationship (Haniffa and Cooke, 2005; Jizi et al., 2014). To represent CEO duality we will use the variable CEODUALITY.

The establishment of committees within the board of directors can help companies to implement social and environmental policies. Although it is still an emerging phenomenon, more and more listed companies with a specific weight within their sector or country of operation are creating their own CSR committees. In this sense, some authors, such as Mallin and Michelon (2011), have found a positive relationship between the presence of this type of committee within the board of directors and the CSR policies carried out by companies. The variable used in our research to represent the CSR committees is CSRCOMMIT.

\subsection{Control variables}

Several control variables are also considered in this research in an attempt to avoid bias in the results. These control variables have been used in previous research into CSR.

The variable SIZE represents the size of the company, and according to Fassin (2008), large companies are highly predisposed to adopt CSR practices, since they have the most 
visibility and are more subject to greater public scrutiny and greater social pressure. In this regard, authors such as Spence (2007), Reverte (2009) and Ali et al. (2017) consider that the size of the company is positively related to the disclosure of their CSR practices. In contrast, small companies focus more on the survival of daily events and on satisfying their employees, treating social and environmental aspects from a more local point of view, which makes CSR less relevant. In addition, they are more likely to feel that full disclosure of their information could jeopardize their competitive position (Watson, Shrives, and Marston, 2002).

ROA (return on assets) is the variable that we use to measure a company's profitability. Several previous research studies have focused on analyzing how profitability affects CSR, although the results obtained have not been unanimous. Liu and Anbomuzhi (2009) came to the conclusion that there is a relationship and that this relationship is positive. Ismail and Chandler (2005) also confirmed this positive relationship, arguing that it is caused by the fact that if managers know how to make a company profitable, they must also have a good knowledge and understanding of CSR, leading to new social relationships and environmental relations. However, other authors, such as McWilliams and Siegel (2000), found a negative association between the two variables, justifying this in that the financial resources used for CSR strategies generate a competitive disadvantage for the companies that promote it with respect to their competitors.

LEVERAGE measures the risk of debt and assesses the company's capacity in terms of financial resources. This variable is measured by the ratio of total debt divided by total assets. It is important to know companies' degree of indebtedness, since if they are in debt, they will not have the funds to carry out CSR practices (Barnea and Rubin, 2010; Reverte, 2009) and, therefore, if they do not perform these practices they will not make them known publicly or through any CSR report.

The CAPITALINTENSITY variable is another of the characteristics that can affect the information presented by companies on CSR and has been used in previous studies by several authors, such as Kolk and Perego (2010), who found that this variable does not affect the voluntary adoption of sustainability assurance statements. In the specific field of CSR reporting, $\mathrm{Xu}$ and Zeng (2016) did not obtain a significant relationship between these two variables either, so we can conclude that capital intensity does not influence the disclosure made by companies about their CSR.

Another control variable that we use is the sector of activity to which the companies analyzed belong. We define this variable as SECTORS. According to García-Ayuso and Larrinaga (2003), some sectors are more likely to report on CSR practices than others, since 
their activities may have a greater impact on society. In this sense, authors such as Young and Marais (2012) think that there are sectors of activity that are considered to be of high impact for stakeholders, among which are basic materials, industrials, utilities or nor-cyclic consumer goods and services. In this case, companies belonging to these sectors of activity will be more likely to disclose CSR information to stakeholders. Finally, we also control for firm and year fixed effects.

\subsection{Econometric analysis model}

In order to test the hypotheses indicated above, a dependency model based on linear regressions was used for panel data. The use of panel data regression models allows CSR to be assessed over time by analyzing observations of several consecutive years for the same sample of companies. In addition, the study is enriched by taking into account the temporal dimension of the data. Thus, this methodology will also allow us to control the effects that CSR practices can undergo over different periods of time, providing the analysis with a certain degree of dynamism and achieving greater consistency and better explanatory power. Finally, the panel data regression models will allow us to obtain more information on the same parameter, which will lead to greater efficiency (Hsiao, 2007).

The model posited is thus as follows:

$C S R=f($ Board structure composition, size, ROA, leverage, capitalintensity, activity sectors)

The model can be empirically estimated using the following equation.

$$
\begin{aligned}
& \text { CSR }_{\text {it }}= \beta_{0}+\beta_{1} \text { BODSIZE }_{i t}+\beta_{2} \text { INBODMEMBERS }_{i t}+\beta_{3} \text { FMLEBOARD }_{i t}+\beta_{4} \\
& \text { CEODUALITY }_{\text {it }}+\beta_{5} \text { CSRCOMMIT }_{i t}+\beta_{6} \text { SIZE }_{i t}+\beta_{7} \text { ROA A }_{i t}+\beta_{8} \text { LEVERAGE }_{i t} \\
&+\beta_{9} \text { CAPITALINTENSITY }_{\text {it }}+\beta_{10} \text { SECTORS }_{i \mathrm{k}}+\eta_{i}+\mu_{i t}
\end{aligned}
$$

Where:

$\boldsymbol{C S} \boldsymbol{R}_{\boldsymbol{i t}}$ is the dependent variable of the model and represents the information on social and

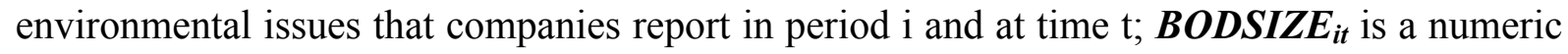
variable that represents the total number of board members; INBODMEMBERS $\boldsymbol{S}_{i t}$ is a numerical variable that represents the percentage of independent directors on the board of directors; FMLEBOARD ${ }_{i t}$ represents the percentage of women on the board of directors; CEODUALITY $_{\text {it }}$ is a dummy variable that takes a value of 1 if the Chair of the board of directors and the CEO are the same person and 0, otherwise; CSRCOMMIT it is a dummy 
variable that takes a value of 1 if the board of directors has a CSR committee and 0 , otherwise; $\boldsymbol{S I Z E _ { i t }}$ represents the size of the company and is measured by the log of total assets of the company; $\boldsymbol{R} \boldsymbol{O} \boldsymbol{A}_{i t}$ is the economic profitability of a company measured as the ratio between operating income and total assets; $\boldsymbol{L E V E R} \boldsymbol{A G} \boldsymbol{E}_{\boldsymbol{i t}}$ is the leverage ratio of a company computed as the ratio between its total debt and assets; CAPITALINTENSITY ${ }_{i t}$ represents capital intensity and is measured by the ratio of long-term or fixed assets over total assets; $\boldsymbol{S E C T O R S}_{i k}$ is a dummy variable that takes the value 1 if the company belongs to sector k and 0 , otherwise. The sectors considered in this research are: basic materials, consumer cyclical, consumer non-cyclical, energy, industrials, technology, telecommunications services and utilities (healthcare is the baseline case for sector dummies).

In all of these variables, subscript $\mathrm{i}$ represents the company and $\mathrm{t}$ refers to the time period. $\beta$ represents the different regression coefficients and the parameters that are to be estimated. The random error term $\left(\varepsilon_{\mathrm{it}}\right)$ is divided into two parts: $\mu_{\mathrm{it}}$, which varies among companies over time, and the individual effect $\eta_{\mathrm{i}}$, which characterizes each company, but is invariant over time.

Finally, the econometric methodology in this case must take into account that the dependent variable takes values between 0 and 112. The most appropriate methodology is the Tobit model for panel data, because it allows us to consider a dependent variable with limits on the right and left, as is the case of the dependent variable. The Tobit model provides coefficients using the maximum likelihood method.

\section{Results}

\subsection{Descriptive analysis}

Table 4 presents the descriptive statistics related to the variables used in the research. The mean of the dependent variable CSR shows that the companies disclose a mean amount of information on social and environmental aspects of 28.35 over a range of 0 to 112 , so it follows that international companies still do not disclose much information on social and environmental aspects. Regarding the size of the board of directors measured by BODSIZE, the average number of members belonging to a board is 10.89 directors. On the other hand, the number of members of the board of directors that are independent is approximately $63 \%$. The descriptive statistics also reveal that the number of women on the boards of directors is approximately $12 \%$. In $29.87 \%$ of the companies, the chairman of the board of directors and the chief executive are the same person and $58.68 \%$ of the boards of directors have a committee to implement CSR policies. The average size of the companies, measured by the 
$\log$ of total assets, is 9.64 , the company average economic profitability is $6.44 \%$ and the leverage, on average, is $1.29 \%$

A correlation matrix was also created. For the sake of brevity, the matrix is not provided, but none of the correlation coefficients provides a value greater than 0.8 . Thus, we can affirm that there are no multicollinearity problems.

\section{INSERT TABLE 4 HERE}

\subsection{Multivariate analysis}

Table 5 shows the results obtained from the models proposed to test the hypotheses posited in the research, considering that they were estimated using the Tobit methodology for panel data.

\section{INSERT TABLE 5 HERE}

One of the independent variables is BODSIZE, which has a positive effect on the CSR variable with a confidence level of $99 \%$. This result shows that larger boards favor CSR practices, as proposed in our hypothesis $\mathrm{H} 1$, which we therefore accept. The results obtained are in line with what was previously suggested by different authors such as Jizi (2017) and Jamali et al. (2008), who showed that board size is one of the variables that positively influence CSR reporting. The argument for this relation is that large boards of directors are able to collect and process information in a timely manner, ensuring an appropriate adjustment between the company and its environment (Zahra, 1989). In the same line of argument, Dalton, Daily, Johnson, and Ellstrand (1999) argue that companies must have large boards of directors that allow them to bring together different managers with diverse skills and experience that will be of great usefulness in resolving conflicts and making decisions. One of these is to carry out CSR practices and report on them.

The independence of the board of directors is another of the independent variables that we consider in the research and that we represent by INBODMEMBERS. In this case, it turned out to be statistically significant with a confidence level of $95 \%$ and with the same sign that had been predicted in the proposed hypothesis and, therefore, we also accept H2. This is one of the variables giving rise to most controversies in the previous literature about the influence it has on company CSR disclosure, because although for some authors the relation is positive (Chen and Jaggi, 2000; Cheng and Courtenay, 2006), for others it is negative (Haniffa and Cooke, 2005; Lim, Matolcsy, and Chow, 2007; Prado-Lorenzo and GarcíaSánchez, 2010). Our study supports this negative relation between the presence of independent, non-executive or external directors, and the disclosure of socially responsible practices by companies. A possible justification for the lack of interest that independent or 
external directors may have in disclosing the social and environmental practices of companies may be a consequence of "a lack of knowledge about the costs that voluntary integration may have for owners" (Rodríguez-Ariza et al., 2014, p.13). Authors such as Prado-Lorenzo and García-Sánchez (2010) observed for an environmental issue of maximum relevance, greenhouse gas emissions, that when companies allow a large amount of information on social and environmental issues to be available to different stakeholders, this may be in detriment to the shareholders. In this case, independent directors may oppose their disclosure precisely to protect and not damage the interests of such shareholders.

The percentage of women on the boards of directors represented by the independent variable FMLEBOARD is positive and statistically significant at $99 \%$, as reflected in Table 5 . Therefore, we accept hypothesis H3, and our results coincide with the idea supported by other research that women who participate in boards of directors are more sensitive to social and environmental issues (Ibrahim and Angelidis, 1994; Marx, 2000) and can influence other members to be socially more responsible (Prado-Lorenzo and García-Sánchez, 2010; Ibrahim and Angelidis, 1994). Other authors also consider the participation of women on boards as highly relevant because they consider them to be more involved than men in social and environmental issues; they manage environmental risks better; and are less likely to compromise quality of life in exchange for material success (Williams, 2003; Liao, Luo, and Tang, 2015).

Our hypothesis 4 shows a positive sign in the sense that CEODUALITY has a positive relationship with disclosure of CSR issues. Thus, the hypothesis H4 has to be rejected because we predict a negative relationship between CEO duality and CSR reporting. This means that even if the positions of chairman of the board of directors and the chief executive of the company fall on the same person, strategies will not necessarily be used that favor the personal interests of the chief executive to the detriment of business interests and a consequent decrease in interest in CSR issues. Therefore, a positive relationship between CEODUALITY and CSR disclosure proposed by previous authors such as Haniffa and Cooke (2005) and Jizi et al. (2014) is confirmed. The supporters of this positive relationship assert that CEO duality facilitates the preparation of reports on CSR with the aim of appeasing the pressure of powerful stakeholders and reducing supervision, or else to increase their permanence in office and remuneration (Jizi, 2017). In addition, Finkelstein and D'Aveni (1994) acknowledge that CEO duality is not always inefficient, especially when the CSR disclosure is used to participate and inform about effective social and environmental 
activities, as a way to protect human capital against short-term-oriented investors (Laeven and Levine, 2009; Pathan, 2009).

The establishment of CSR committees within the board of directors of the companies positively affects the disclosure of the CSR practices they carry out, so we accept the proposed H5 with a level of confidence of 99\%. Mackenzie (2007) warns of the importance of including CSRCOMMIT to assist management in the formulation of CSR strategies and Shaukat, Qiu, and Trojanowski (2016) show that having this type of committee indicates a public recognition of the importance of environmental and social responsibilities for the company, known as the role of reputation. Note that although it is an emerging issue, the results obtained are in line with those previously obtained by other authors such as Mallin and Michelon (2011), who found a positive relationship between the presence of such committees within the board of directors and the CSR policies carried out by the companies.

Regarding the control variables, the SIZE variable is statistically significant at a confidence level of $95 \%$ for all models, except when the independent variable is INBODMEMBERS. This result confirms what was established by previous investigations, such as those carried out by Fassin (2008), Spence (2007) or Reverte (2009), which show that large companies are highly inclined to adopt CSR practices, since large companies are the most visible and are more subject to greater public scrutiny and greater social pressure. ROA presents a statistically significant relationship at $90 \%$ for two models, although it is negative, and therefore we consider what was established by McWilliams and Siegel (2000), in the sense that the financial resources used for CSR strategies generate a competitive disadvantage for companies that promote it with respect to their competitors.

LEVERAGE does not show statistical significance and, therefore, does not influence the performance or dissemination of CSR practices by companies. Thus, it is not observed that lenders show interest in the information on business performance from the social and environmental point of view. On the other hand, as indicated by Barnea and Rubin (2010), it is important to know companies' degree of indebtedness, since if they are indebted, they will not have the funds to carry out CSR practices and, therefore, if they do not carry out said practices, they cannot be disclosed publicly or through any CSR report.

CAPITALINTENSITY does not show statistical significance in any of the models, and thus the results obtained in previous studies such as those by Kolk and Perego (2010) or $\mathrm{Xu}$ and Zeng (2016) are confirmed, revealing that this variable does not affect the disclosure companies make in regard to their CSR. 
With respect to SECTORS, the variable that represents the sectors of activity, it is important to highlight the behavior of some of them, such as basic materials, industrials, utilities or nor-cyclic consumer goods and services, which are statistically significant (either at $90 \%, 95 \%$ or $99 \%$ ). These results confirm what was indicated by Young and Marais (2012), who found that there are sectors of activity that are considered as high impact for stakeholders, among which are basic materials, industrials, utilities or nor-cyclic consumer goods and services. In this case, companies belonging to these sectors of activity will be more likely to disclose CSR information to stakeholders.

Finally, we have also considered the possible problems of endogeneity that may arise between the different variables representing board composition and the disclosure of CSR (Villalonga and Amit, 2006). To analyze the problems of endogeneity that may have arisen, we have run several analyses using the Tobit methodology for panel data, but lagging our independent variables in our regressions, in line with Hartzell and Sarks (2003) and Ozkan (2007), who support the use of lagged explanatory variables to alleviate possible endogeneity concerns. The results obtained are consistent with the core findings provided earlier and, thus, we can confirm that potential endogeneity is not a concern in our analysis. The results with lagged explanatory variables confirm the findings previously shown ${ }^{1}$.

\subsection{Sensibility analysis}

To provide more validity to the results obtained in the previous analysis, we proceeded to make a new estimation with the same Tobit methodology for panel data, but this time considering a new dependent variable called CSR1, which was obtained by dividing the total sum of each of the items by the total number of items, which is 112 , thus obtaining a new dependent variable that oscillates between the values 0 and 1 . The results are similar to those obtained previously, since all independent variables show a positive statistical significance with CSR1, except INBODMEMBERS, which is negative, in line with what was revealed in the base model under study ${ }^{2}$.

\section{Conclusions}

CSR disclosure has become a relevant tool for firms to be legitimated by society, particularly stakeholders. When firms report CSR matters, they aim to signal to all stakeholders that they are involved with social and environmental issues. However, the mere presence of boards in firms does not imply more CSR reporting; rather, this will depend on what attributes boards have. Thus, in this research study our aim was to analyze how board 
characteristics of international firms affect CSR reporting. Concretely, we examine what effect board size, board independence, board gender diversity, CEO duality and CSR board committee have on the disclosure of CSR information.

Our findings show that board size, board gender diversity and CSR board committees are positively associated with CSR reporting, while board independence has a negative impact on CSR disclosure. CEO duality shows a significant impact on CSR reporting, opposite to our predictions.

These results may have several implications. First, our evidence suggests that board composition is a crucial aspect that firms should take into account when making strategic decisions such as CSR reporting. International firms interested in showing to all stakeholders and society their commitment to the reporting of CSR issues should set up boards with a high number of members, with women directors, with CSR committees and with CEOs also holding the position of chairman of the board. However, the presence of independent directors should be minimized since these directors, according to our findings, discourage the reporting of CSR information. It seems that independent directors do not play an effective role supervising insiders and, therefore, the strong power that regulatory bodies and corporate good governance codes, among others, give them to reinforce their presence on boards might not be justified. Firms should feel free to form their boards and in the case of independent directors, they should introduce the appropriate number in order to protect minority shareholders' rights against dominant shareholders' power, but not expect them to perform an effective monitoring role by, for instance, enhancing CSR disclosure. These ideas are supported by Gutiérrez and Sáez (2013) and by Le Mire and Gilligan (2013), who argue that regulators are paying increasing attention to the formal independence of independent directors, as corporate governance laws seem to conceive, but this acknowledgment is disappointing. Secondly, researchers should delve more deeply to find out what other attributes of independent directors should be considered, since their mere presence on boards reduces the reporting of CSR matters. The lack of an appropriate background or experience in CSR topics might explain this behavior, but this question needs to be examined. Characteristics other than expertise and skills, such as their sensitivity toward CSR issues or their ethics, might be tested, although it has to be acknowledged that these features are difficult to measure. Finally, worldwide regulatory bodies should be aware that CSR information should not be the object of voluntary disclosure, but rather should be compulsory for firms. This information is useful for current or potential investors, for capital markets and other stakeholders. Thus, policy-makers should take a step forward and implement laws and 
programs that oblige firms to disclose CSR matters, given their important content for all business, social and environmental agents.

Our conclusions may open new lines of research in the future. First, it would be interesting to examine what role independent directors could perform on boards concerning CSR disclosure if their abilities, skills, knowledge, expertise and background are considered. Finally, researchers should shed new light on how the experience and background, not only of independent directors, but of all directors on the board, have an impact on the CSR reporting of international firms.

\section{Notes}

${ }^{1}$ All analyses on endogeneity were carried out, although not presented in the paper for reasons of space. They can be requested from the authors, who will gladly provide them.

${ }^{2}$ All analyses on sensitivity were carried out, although not presented in the paper for reasons of space. They can be requested from the authors, who will gladly provide them.

\section{References}

Adnan, S.M., Staden, V.S., and Hay, D. (2010). Do culture and governance structure influence CSR reporting quality: Evidence from China, India, Malaysia and the United Kingdom. Proceedings of the 6th Asia Pacific Interdisciplinary Research in Accounting Conference, Sydney. 2010.

Ali, W., Frynas, J.and Mahmood, Z. (2017). Determinants of Corporate Social Responsibility (CSR) disclosure in developed and developing countries: A literature review. Corporate Social Responsibility and Environmental Management, DOI: 10.1002/csr.1410.

Arena, C., Bozzolan, S., and Michelon, G. (2015). Environmental reporting: Transparency to stakeholders or stakeholder manipulation?. An analysis of disclosure tone and the role of the board of directors. Corporate Social Responsibility and Environmental Management, 22(6): 346-361.

Arvidsson, S. (2010). Communication of corporate social responsibility: a study of the views of management teams in large companies. Journal of Business Ethics, 96: 339-354

Agrawal, A., and Knoeber, C. (1996). Firm performance and mechanisms to control agency problems between managers and shareholders. Journal of Finance and Quantitative Analysis, 31(3): 377-397.

Arellano, M. (2003). Panel data econometrics. Oxford University Press. Oxford.

Arora, P., and Dharwadkar R. (2011). Corporate governance and corporate social responsibility (CSR): the moderating roles of attainment discrepancy and organization slack. Corporate Governance: An International Review, 19 (2): 136-152.

Barako, D., and Brown, A. (2008). Corporate social reporting and board representation: evidence from the Kenyan banking sector. Journal of Management and Governance, 12: 309-324.

Barnea, A., and Rubin, A. (2010). Corporate social responsibility as a conflict between shareholders. Journal of Business Ethics, 97(1): 71-86.

Barry, T. Lepetit, L., and Tarazi, A. (2011). Ownership structure and risk in publicly held and privately owned banks. Journal of Banking and Finance, 35(5): 1327-1340. 
Bear, S., Rahman, N., and Post, C. (2010). The impact of board diversity and gender composition on corporate social responsibility and firm reputation. Journal of Business Ethics, 97, 207-221.

Bird, B., and Brush, C. (2002). A gendered perspective on organizational creation. Entrepreneurship: Theory and Practice, 26(3): 41-65.

Brammer, S., Millington, A. and Pavelin, S. (2007). Gender and ethnic diversity among UK corporate boards. Corporate Governance: An International Review, 15(2): 393-403.

Brown, W. O., Helland, E., and Smith, J. K. (2006). Corporate philanthropic practices. Journal of Corporate Finance, 12, 855-877.

Carrasco, A., and Laffarga, J. (2007). La diversidad en el cóodigo de buen gobierno. Conocimiento, Innovación y Emprendedores; Camino al Futuro. Pecvina, 5: 1-25.

Carroll, A.B. (1979). A three-dimensional conceptual model of corporate performance. The Academy of Management Review, 4: 497-505.

Carter, D. A., Simkins, B. J., and Simpson, W. G. (2003). Corporate governance, board diversity, and firm value, Financial Review, 38: 33-53.

Chan, M.C., Watson, J. and Woodliff, D. (2014). Corporate governance quality and CSR disclosure. Journal of Business Ethics, 125(1): 59-73.

Chau, G., and Gray, S. (2010). Family ownership, board independence and voluntary disclosure: evidence from Hong Kong. Journal of International Accounting, Auditing and Taxation, 19 (2): 93-109.

Chen, S., and Bouvain, P. (2009). Is corporate responsibility converging? A comparison of corporate responsibility reporting in the USA, UK, Australia, and Germany. Journal of Business Ethics, 8: 299-317.

Chen, C., and Jaggi, B. (2000). Association between Independent non-executive Directors, Family Control and Financial Disclosures in Hong Kong, Journal of Accounting and Public Policy, 19: 285-310.

Cheng, E., and Courtenay, S. (2006). Board composition, regulatory regime and voluntary disclosure. International Journal of Accounting, 41(3): 262-289.

Cormier, D., Ledoux, M-J., Magnan, M., and Aerts, W. (2010). Corporate governance and information asymmetry between managers and investors. Corporate Governance, 10(5): 574-589.

Dalton, D. R., Daily, C. M., Johnson, J. L., and Ellstrand, A. E. (1999). Number of directors and financial performance: A meta-analysis. Academy of Management Journal, 42(6): 674-686.

Davis, M.H., Capobianco, S., and Kraus, L.A. (2010). Gender differences in responding to conflict in the workplace: Evidence from a large sample of working adults. Sex Roles, 63, 500-514.

De Graaf, F. J., and Stoelhorst,W. (2009). The role of governance in corporate social responsibility: Lessons from Dutch finance. Business and Society, 52: 282-317.

De-Mandojana, N., and Aragon-Correa J. (2015). Boards and sustainability: the contingent influence of director interlocks on corporate environmental performance. Business Strategy and the Environment, 24: 499-517.

Dey, A. (2008). Corporate governance and agency conflicts. Journal of Accounting Research, 46(5): 1143-1181.

Dias, A., Rodrigues, L.L., and Craig, R. (2017). Corporate governance effects on social responsibility disclosures. Australasian Accounting Business and Financial Journal, 11(2), 3-22.

Donnelly, R., and Mulcahy, M. (2008). Board structure, ownership, and voluntary disclosure in Ireland. Corporate Governance: An International Review, 16 (5): 416-429. 
Du, S., Bhattacharya, C., and Sen, S. (2010). Maximizing business returns to corporate social responsibility: The role of CSR communication. International Journal of Management Reviews, 12: 8-19.

Eagly, A. H. and Johannesen-Schmidt, M. C. (2001). The leadership styles of women and men. Journal of Social Issues, 57: 781-797.

Eng, L. L., and Mak, Y. T. (2003). Corporate governance and voluntary disclosure. Journal of Accounting and Public Policy, 22: 325-345.

Evans, D. (2010). Aspiring to leadership a woman's world? An example of developments in France. Cross Cultural Management: An International Journal, 17(4): 347-367.

Fassin, Y. (2008). Imperfections and Shortcomings of the Stakeholder Model's Graphical Representation, Journal of Business Ethics, 80 (4): 879-888.

Fernandez-Feijoo, B., Romero, S., and Ruiz, S. (2012). Does board gender composition affect corporate social responsibility reporting?. International Journal of Business and Social Science, 3: 31-38.

Fernandez-Feijoo, B., Romero, S., and Ruiz-Blanco, S. (2014). Women on boards: Do they affect sustainability reporting?. Corporate Social Responsibility and Environmental Management, 21: 351-264.

Finkelstein, S., and D'Aveni., R. (1994). CEO duality as a double-edged sword: how boards of directors balance entrenchment avoidance and unity of command. Academy of Management Journal, 37(5): 1079-1108.

Fligstein, N. (1991). The structural transformation of American industry: An institutional account of the causes of diversification in the largest firms, 1919-1979. In W. W. Powell and P. J. DiMaggio (Eds.), The new institutionalism in organizational analysis: 311-36. Chicago, IL: University of Chicago Press.

Freeman, R. E. (1984). Strategic management: A stakeholder approach. Boston, MA: Pitman.

Frías-Aceituno, J. V., Rodríguez-Ariza, L., and García-Sánchez, I. M. (2013). The role of the board in the dissemination of integrated corporate social reporting. Corporate Social Responsibility and Environmental Management, 20: 219-33.

Fuente, J. A., García-Sánchez, I. M., and Lozano, M. B. (2017). The role of the board of directors in the adoption of GRI guidelines for the disclosure of CSR information. Journal of Cleaner Production, 141: 737-750.

Gallego-Álvarez, I., and Ortas, E. (2017). Corporate environmental sustainability reporting in the context of national cultures: A quantile regression approach. International Business Review, 2: 337-353.

García-Ayuso, M., and Larrinaga, C. (2003). Environmental disclosure in Spain: Corporate characteristics and media exposure. Spanish Journal Finance and Accounting, 115: 184-214.

García-Meca, E., and Pucheta-Martínez, M.C. (2017). How institutional investors on boards impact on stakeholder engagement and corporate social responsibility reporting. Corporate Social Responsibility and Environmental Management, DOI: $10.1002 /$ csr. 1451 .

Giannarakis, G. (2014). The determinants influencing the extent of CSR disclosure. International Journal of Law and Management, 56(5): 393-416.

Gray R, Kouhy R., and Lavers, S. (1995). Corporate social and environmental reporting a review of the literature and a longitudinal study of UK disclosure. Accounting, Auditing and Accountability Journal, 8(2): 47-77.

Guest, P. M. (2009). The impact of board size on firm performance: Evidence from the UK. European Journal of Finance, 15(4): 385-404.

Gutiérrez, M., and Sáez, M. (2013). Deconstructing independent directors. Journal of Corporate Law Studies, 13(1): 63-94. 
Haniffa, R., and Cooke, T. (2005). The impact of culture and governance on corporate social reporting. Journal of Accounting and Public Policy, 24(5): 391-430.

Hartzell, J.C., and Starks, L.T. (2003). Institutional investors and executive compensation. Journal of Finance, 58(6): 2351-2374.

Hillman, A.J., Cannella Jr, A, and Harris, I.C. (2002). Women and Racial Minorities in the Boardroom: How do Directors Differ?. Journal of Management, 28: 747-763.

Hooghiemstra R. (2000). Corporate communication and impression management: new perspectives why companies engage in corporate social reporting. Journal of Business Ethics, 27(1-2): 55-68.

Hsiao, CH. (2007). Panel data analysis-advantages and challenges. Journal of Business Ethics, 16: 1-22.

Huafang, X., and Jianguo, Y. (2007). Ownership structure, board composition and corporate voluntary disclosure: Evidence from listed companies in China. Managerial Auditing Journal, 22: 604-619.

Huang, Ch-L., and Kung, F-H. (2010). Drivers of environmental disclosure and stakeholder expectation: Evidence from Taiwan. Journal of Business Ethics, 96: 435-451.

Ibrahim, N. A., and Angelidis, J. P. (1994). Effect of board members' gender on corporate social responsiveness orientation. Journal of Applied Business Research, 10: 35-43.

Ismail, K., and Chandler R. (2005). Disclosure in the quarterly reports of Malaysian companies. Financial Reporting, Regulation and Governance, 4 (1): 1-25.

Jain, T., and Jamali, D. (2016). Looking inside the black box: the effect of corporate governance on corporate social responsibility. Corporate Governance: An International Review, 24(3): 253-273.

Jamali, D., Safieddine, A., and Rabbath, M. (2008). Corporate governance and corporate social responsibility synergies and interrelationships. Corporate Governance: An International Review, 16(5): 443-459.

Jensen, M. C., and Meckling, W.H. (1976). Theory of the firm: Managerial behaviour, agency costs and ownership structure. Journal of Financial Economics, 3: 305-360.

Jiraporn, P. and Chintrakarn, P. (2013). Corporate social responsibility (CSR) and CEO luck: Are lucky CEOs socially responsible?. Applied Economics Letters, 20: 1036-1039

Jizi, M. (2017). The Influence of Board Composition on Sustainable Development Disclosure. Business Strategy and the Environment, 26: 640-655.

Jizi, M., Salama, A., Dixon, R., and Stratling, R. (2014). Corporate governance and corporate social responsibility disclosure: evidence from the US banking sector. Journal of Business Ethics, 125(4): 601-615.

John, K., and Senbet, L. W. (1998). Corporate governance and board effectiveness. Journal of Banking and Finance, 22(4): 371-403.

Johnson, S. G., Schnatterly, K., and Hill, A. D. (2012). Board composition beyond independence: Social capital, human capital, and demographics. Journal of Management, 39: 232-62.

Kalsie, A., and Shrivastav, S.M. (2016). Analysis of Board Size and Firm Performance: Evidence from NSE Companies Using Panel Data Approach. Indian Journal of Corporate Governance, 9(2): 148-172.

Keasey, K., and Hudson, R. (2012). Non-executive directors and the Higgs consultation paper, 'Review of the role and effectiveness of non-executive directors'. Journal of Financial Regulation and Compliance, 10 (4): 361-371.

Kent, P., and Monem, R. (2008). What drives TBL reporting: Good governance or threat to legitimacy?. Australian Accounting Review, 18:297-309. 
Khan, M. H. U. Z. (2010). The effect of corporate governance elements on corporate social responsibility (CSR) reporting: Empirical evidence from private commercial banks of Bangladesh. International Journal of Law and Management, 52: 82-109.

Kiel, G., and Nicholson, G. (2003). Board composition and corporate performance: How the Australian experience inform contrasting theories of corporate governance, Corporate Governance: An International Review, 11: 189-205.

Kim, H. (2013). Glass fence thicker than glass ceiling: The puzzling gaps of women's leadership in Korea. In J. Rajasekar (Ed.), Culture and gender in leadership: Perspectives from the Middle East and Asia (pp. 253-274). Hampshire, England: Palgrave Macmillan.

Kolk, A., and Perego, P. (2010). Determinants of the Adoption of Sustainability Assurance Statements: An International Investigation. Business Strategy and the Environment, 19: 182-198.

Kolk, A., and Pinkse, J. (2010). The integration of corporate governance in corporate social responsibility disclosures. Corporate Social Responsibility and Environmental Management, 17: 15-26.

Konadu, R. (2017). Gender diversity impact on corporate social responsibility (CSR) and Greenhouse Gas emissions in the UK. Economics and Business Review, 3(1):127-148.

Laeven, L., and Levine, R. (2009). Bank governance, regulation and risk taking. Journal of Financial Economics, 93 (2): 259-275.

La Porta, R., Lopez-de-Silane, F., Shleifer, A., and Vishny, R. W. (2000). Investor protection and corporate governance. Journal of Financial Economics, 58: 3-27.

Le Mire, S., and Gilligan, G. (2013). Independence and independent company directors. Journal of Corporate Law Studies, 13(2): 443-475.

Larrieta-Rubín de Celis, I., Velasco-Balmaseda, E., Fernández de Bobadilla, S., AlonsoAlmeida, M.D.M., and Intxaurburu-Clemente, G. (2015). Does having women managers lead to increased gender equality practices in corporate social responsibility?. Business Ethics: A European Review, 24(1): 91-110.

Lee, Y.K., Kim, Y.S., Lee, K.H., and Li, D. (2012). The impact of CSR on relationship quality and relationship outcomes: a perspective of service employees. International Journal of Hospitality Management, 31: 745-756.

Leire, C., and Mont, O. (2010). The implementation of socially responsible purchasing. Corporate Social Responsibility and Environmental Management, 17: 27-39.

Levi, M., Li, K., and Zhang, F. (2014). Director gender and mergers and acquisitions. Journal of Corporate Finance, 28: 185-200.

Liao, L., Luo, L., Tang, Q. (2015). Gender diversity, board independence, environmental committee and greenhouse gas disclosure. British Accounting Review, 47: 409-424.

Lim, S., Matolcsy, Z., and Chow, D. (2007). The Association between Board Composition and Different Types of Voluntary Disclosure. European Accounting Review, 16: 555583.

Liu, W. K. (2010). The environmental responsibility of multinational corporations. The Journal of American Academy of Business, 15: 81-88.

Liu, X., and Anbumozhi, V. (2009). Determinant factors of corporate environmental information disclosure: an empirical study of Chinese listed companies. Journal of Cleaner production, 17 (6): 593-600.

Lone, E.J., Ali, A. and Khan, I. (2016). Corporate governance and corporate social responsibility disclosure: evidence from Pakistan. Corporate Governance: The International Journal of Business in Society, 16(5): 785-797.

Michelon, G. and Parbonetti, A. (2012). The effect of corporate governance on sustainability Disclosure. Journal of Management and Governance, 16(3): 477-509. 
Mackenzie, C. (2007). Boards, incentives and corporate social responsibility: The case for a change of emphasis. Corporate Governance: An International Review, 15(5): 935943.

Mallin, C. A., and Michelon, G. (2011). Board reputation attributes and corporate social performance: An empirical investigation of the US Best Corporate Citizens. Accounting and Business Research, 41(2): 119-144.

Mallin, C., Michelon, G., and Raggi, D. (2013). Monitoring intensity and stakeholders' orientation: How does governance affect social and environmental disclosure? Journal of Business Ethics, 114(1): 29-43.

Man, C.K., and Wong, B. (2013). Corporate governance and earnings management: a survey. Journal of Applied Business Research, 29(2): 391-418.

Marx, J. D. (2000). Women and human services giving. Social Work, 45: 27-38.

Matsa, D.A., and Miller, A.R. (2013). A female style in corporate leadership? Evidence from quotas. American Economic Journal: Applied Economics, 5(3): 136-169.

McWilliams, A., and Siegel, D. (2000). Corporate social responsibility and financial performance: Correlation or misspecification?. Strategic Management Journal, 2: 3352 .

Melero, E. (2011). Are workplaces with many women in management run differently?. Journal of Business Research, 84(4): 385-393.

Montiel, I., and Delgado-Ceballos, J. (2014). Defining and measuring corporate sustainability are we there yet?. Organization and Environment, 27(2): 113-139.

Nakano, M. and Nguyen, P. (2012). Board size and corporate risk taking: Further evidence from Japan, Corporate Governance: An International Review, 20: 369-387.

Nielsen, S.T., and Huse, M. (2010). The Contribution of Women on Boards of Directors: Going beyond the Surface. Corporate Governance: An International Review, 18(2): 136-148.

Ntim, C. G., and Soobaroyen, T. (2013). Corporate governance and performance in socially responsible corporations: New empirical insights from a neo-institutional framework. Corporate Governance: An International Review, 21: 468-494.

Obigbemi, I.F., Omolehinwa, E.O., Mukoro, D.O., Ben-Caleb, E., and Olusanmi, O.A. (2016). Earnings management and board structure. Evidence from Nigeria. SAGE Open, DOI: $10.1177 / 2158244016667992$

Ozkan, N. (2007). Do corporate governance mechanism influence CEO compensation? An empirical investigation of UK companies. Journal of Multinational Financial Management, 17(5): 349-364.

Pathan, S. (2009). Strong boards, CEO power and bank risk-taking. Journal of Banking and Finance, 33(7): 1340-1350.

Prado-Lorenzo, J. M. and Garcia-Sanchez, I. M. (2010). The role of the board of directors in disseminating relevant information on greenhouse gases. Journal of Business Ethics, 97(3): 391-424.

Prado-Lorenzo, J. M., Gallego-Alvarez, I., and Garcia-Sánchez, I. M. (2009). Stakeholder engagement and corporate social responsibility reporting: The ownership structure effect. Corporate Social Responsibility and Environmental Management, 16: 94-107.

Pucheta-Martínez, M.C., Bel-Oms, I., and Olcina-Sempere, G. (2016). Corporate governance, female directors and quality of financial information. Business Ethics: A European Review, 25(4): 363-385.

Rao, K. and Tilt, C. (2016). Board composition and corporate social responsibility: The role of diversity, gender, strategy and decision making. Journal of Business Ethics, 138: 327-347. 
Rao, K. K., Tilt, C. A., and Lester, L. H. (2012). Corporate governance and environmental reporting: An Australian study. Corporate Governance, 12: 143-163.

Reeb, D., and Zhao, W. (2013). Director capital and corporate disclosure quality. Journal of Accounting and Public Policy, 32(4): 191-212.

Rechner, P. L. and Dalton, D. R. (1991). CEO duality and organizational performance: A longitudinal analysis, Strategic Management Journal, 12: 155-160.

Reverte, C. (2009). Determinants of Corporate Social Responsibility Disclosure Ratings by Spanish Listed Firms, Journal of Business Ethics, 88: 351-366.

Rogelberg, S. G. and Rumery, S. M. (1996). Gender diversity, team decision quality, time on task, and interpersonal cohesion. Small Group Research, 27(1): 79-90.

Rodríguez-Ariza, L., Frías-Aceituno, J. V., and García-Rubio, R. (2014). El consejo de administración y las memorias de sostenibilidad. Spanish Accounting Review, 17: 516.

Rupp, D.E., and Mallory, D.B. (2015). Corporate social responsibility: psychological, personcentric, and progressing. Annual Review of Organizational Psychology and Organizational Behavior, 2: 211-236.

Said, R., Zainuddin, Y. H., and Haron, H. (2009). The relationship between corporate social responsibility disclosure and corporate governance characteristics in Malaysian public listed companies. Social Responsibility Journal, 5: 212-226.

Shaukat, A., Qiu, Y., and Trojanowski, G. (2016). Board Attributes, Corporate Social Responsibility Strategy, and Corporate Environmental and Social Performance. Journal of Business Ethics, 135: 569-585.

Simpson, W., and Kohers, T. (2002). The link between corporate social and financial performance: evidence from the banking industry. Journal of Business Ethics, 35(2): 97-109.

Spence, L.J. (2007). CSR and Small Business in a European Policy Context: The Five 'C's of CSR and Small Business Research Agenda 2007. Business and Society Review, 112 (4): 533-552.

Sundarasen, Sh. D.D., Je-Yen, T., and Rajangam, N. (2016). Board composition and corporate social responsibility in an emerging market. Corporate Governance, 16(1): $35-53$.

Surroca, J., and Tribo, J. A. (2008). Managerial entrenchment and corporate social performance. Journal of Business Finance and Accounting, 35: 748-89.

Tagesson, T., Blank, V., Broberg, P., and Collin S.O. (2009). What Explains the Extent and Content of Social and Environmental Disclosures on Corporate Websites: A Study of Social and Environmental Reporting in Swedish Listed Corporations. Corporate Social Responsibility and Environmental Management, 16: 352-364.

Tamini, N., and Sebastianelli, R. (2017). Transparency among SandP 500 companies: an analysis of ESG disclosure scores. Management Decision, 55(8): 1660-1680.

Vigneau, Humphreys, M. and Moon, J. (2015): How do firms comply with international sustainability standards?. Processes and consequences of adopting the global reporting initiative. Journal of Business Ethics, 131(2): 469-486.

Villalonga, B., and Amit, R. (2006). How do family ownership, control and management affect firm value?. Journal of financial Economics, 8(2), 385-417.

Wahyuni, D., Rankin, M., and Windsor, C. (2009). Towards emissions trading: the role of environmental management systems in voluntarily disclosing greenhouse gas emissions. Paper presented at AFAANZ Conference 2009, Adelaide, Australia.

Wan-Hussin, W. N. (2009). The impact of family-firm structure and board composition on corporate transparency: evidence based on segment disclosures in Malaysia. International Journal of Accounting, 44: 313-333. 
Watson, A., Shrives, P., and Marston, C. (2002). Voluntary disclosure of accounting ratios in the UK. British Accounting Review, 34 (2), 289-313.

Williams R. (2003). Women on corporate boards of directors and their influence on corporate philanthropy. Journal of Business Ethics, 42: 1-10.

$\mathrm{Xu}, \mathrm{B}$. and Zeng, T. (2016). Profitability, state ownership, tax reporting and corporate social responsibility: evidence from Chinese listed firms. Social Responsibility Journal, 12(1): 23-31.

Young, S. and Marais, M. (2012). A Multi-level Perspective of CSR Reporting: The Implications of National Institutions and Industry Risk Characteristics. Corporate Governance: An International Review, 20 (5): 432-450

Zahra, S. A. and Stanton, W. W. (1988). The implications of board of directors' composition on corporate strategy and performance. International Journal of Management, 5(2): 229-236.

Zahra, S. A. (1989). Boards of directors and corporate social responsibility performance. European Management Journal, 7(2): 240-247.

Table 1

Number of observations by country

\begin{tabular}{|c|c|c|c|c|c|c|c|}
\hline Country & Observations & Percentage & Cum. & Country & Observations & Percentage & Cum. \\
\hline Australia & 817 & 6.2 & 6.2 & Japan & 1,789 & 13.58 & 49.47 \\
\hline Austria & 41 & 0.31 & 6.51 & Jersey & 20 & 0.15 & 49.62 \\
\hline Belgium & 97 & 0.74 & 7.25 & Luxembourg & 65 & 0.49 & 50.11 \\
\hline Bermuda & 15 & 0.11 & 7.36 & Macau & 5 & 0.04 & 50.15 \\
\hline Brazil & 257 & 1.95 & 9.31 & Mexico & 124 & 0.94 & 51.09 \\
\hline Canada & 1,155 & 8.76 & 18.08 & Netherlands & 220 & 1.67 & 52.76 \\
\hline Chile & 110 & 0.83 & 18.91 & New Zealand & 53 & 0.4 & 53.16 \\
\hline China & 342 & 2.6 & 21.51 & Norway & 70 & 0.53 & 53.7 \\
\hline Czech & & & & Papua New & & & \\
\hline Republic & 8 & 0.06 & 21.57 & Guinea & 7 & 0.05 & 53.75 \\
\hline Denmark & 115 & 0.87 & 22.44 & Portugal & 29 & 0.22 & 53.97 \\
\hline Egypt & 22 & 0.17 & 22.61 & Russia & 190 & 1.44 & 55.41 \\
\hline Finland & 142 & 1.08 & 23.68 & South Africa & 80 & 0.61 & 56.02 \\
\hline France & 578 & 4.39 & 28.07 & Spain & 211 & 1.6 & 57.62 \\
\hline Germany & 407 & 3.09 & 31.16 & Sweden & 261 & 1.98 & 59.6 \\
\hline Greece & 10 & 0.08 & 31.23 & Switzerland & 393 & 2.98 & 62.58 \\
\hline Hong Kong & 128 & 0.97 & 32.21 & $\begin{array}{l}\text { Thailand } \\
\text { United }\end{array}$ & 97 & 0.74 & 63.32 \\
\hline India & 171 & 1.3 & 33.5 & Kingdom & 1,209 & 9.17 & 72.49 \\
\hline Ireland; & & & & United States & & & \\
\hline Republic of & 175 & 1.33 & 34.83 & of America & 3,625 & 27.51 & 100 \\
\hline Isle of Man & 1 & 0.01 & 34.84 & Total & 13,178 & 100 & \\
\hline Israel & 6 & 0.05 & 34.88 & & & & \\
\hline Italy & 133 & 1.01 & 35.89 & & & & \\
\hline
\end{tabular}


Table 2

Number of observations by activity sector

\begin{tabular}{lrrr}
\hline \multicolumn{1}{c}{ TRBC economic sector name } & $\begin{array}{r}\text { Number of } \\
\text { observations }\end{array}$ & Percentage & Cum. \\
\hline Basic Materials & 1,851 & 14.05 & 14.05 \\
Consumer Cyclicals & 2,484 & 18.85 & 32.9 \\
Consumer Non-Cyclicals & 1,298 & 9.85 & 42.75 \\
Energy & 1,313 & 9.96 & 52.71 \\
Healthcare & 1,023 & 7.76 & 60.47 \\
Industrials & 2,816 & 21.37 & 81.84 \\
Technology & 1,032 & 7.83 & 89.67 \\
Telecommunications Services & 521 & 3.95 & 93.63 \\
Utilities & 840 & 6.37 & 100 \\
Total & $\mathbf{1 3 , 1 7 8}$ & $\mathbf{1 0 0}$ &
\end{tabular}


Table 3

Corporate social responsibility disclosure

\begin{tabular}{|c|c|c|c|c|c|c|}
\hline \multirow[b]{2}{*}{ Resource use } & \multicolumn{3}{|c|}{ Environmental } & \multicolumn{2}{|l|}{ Social } & \multirow[b]{2}{*}{$\begin{array}{l}\text { Product } \\
\text { responsibility }\end{array}$} \\
\hline & Emissions & Innovation & Workforce & $\begin{array}{l}\text { Human } \\
\text { rights }\end{array}$ & Community & \\
\hline $\begin{array}{l}\text { Resource reduction } \\
\text { policy }\end{array}$ & $\begin{array}{l}\text { Policy } \\
\text { emissions }\end{array}$ & $\begin{array}{l}\text { Environmental } \\
\text { products }\end{array}$ & $\begin{array}{l}\text { Health and } \\
\text { safety policy } \\
\text { Policy }\end{array}$ & $\begin{array}{l}\text { Human rights } \\
\text { policy }\end{array}$ & $\begin{array}{l}\text { Employee } \\
\text { engagement } \\
\text { volunt work }\end{array}$ & $\begin{array}{l}\text { Policy customer } \\
\text { health and safety }\end{array}$ \\
\hline $\begin{array}{l}\text { Policy water } \\
\text { efficiency }\end{array}$ & $\begin{array}{l}\text { Targets } \\
\text { emissions }\end{array}$ & $\begin{array}{l}\text { Eco-design } \\
\text { products }\end{array}$ & $\begin{array}{l}\text { employee } \\
\text { health and } \\
\text { safety }\end{array}$ & $\begin{array}{l}\text { Policy } \\
\text { freedom of } \\
\text { association }\end{array}$ & $\begin{array}{l}\text { Corporate } \\
\text { responsibility } \\
\text { awards }\end{array}$ & $\begin{array}{l}\text { Policy data } \\
\text { privacy }\end{array}$ \\
\hline $\begin{array}{l}\text { Policy energy } \\
\text { efficiency }\end{array}$ & $\begin{array}{l}\text { Biodiversity } \\
\text { impact } \\
\text { reduction }\end{array}$ & Noise reduction & $\begin{array}{l}\text { Policy supply } \\
\text { chain health } \\
\text { and safety }\end{array}$ & $\begin{array}{l}\text { Policy child } \\
\text { labor }\end{array}$ & $\begin{array}{l}\text { Product sales } \\
\text { at discount to } \\
\text { emerging } \\
\text { markets }\end{array}$ & $\begin{array}{l}\text { Policy } \\
\text { responsible } \\
\text { marketing }\end{array}$ \\
\hline $\begin{array}{l}\text { Policy sustainable } \\
\text { packaging }\end{array}$ & $\begin{array}{l}\text { Emissions } \\
\text { trading }\end{array}$ & Hybrid vehicles & $\begin{array}{l}\text { Training and } \\
\text { development } \\
\text { policy }\end{array}$ & $\begin{array}{l}\text { Policy forced } \\
\text { labor }\end{array}$ & $\begin{array}{l}\text { Diseases of } \\
\text { the developing } \\
\text { world }\end{array}$ & Policy fair trade \\
\hline $\begin{array}{l}\text { Policy environment } \\
\text { supply chain }\end{array}$ & $\begin{array}{l}\text { Climate change } \\
\text { commercial } \\
\text { risks } \\
\text { opportunities }\end{array}$ & $\begin{array}{l}\text { Environmental } \\
\text { assets under } \\
\text { MGT }\end{array}$ & $\begin{array}{l}\text { Policy skills } \\
\text { training }\end{array}$ & $\begin{array}{l}\text { Policy human } \\
\text { rights }\end{array}$ & $\begin{array}{l}\text { Bribery } \\
\text { corruption and } \\
\text { fraud } \\
\text { controversies }\end{array}$ & $\begin{array}{l}\text { Product } \\
\text { responsibility } \\
\text { monitor }\end{array}$ \\
\hline $\begin{array}{l}\text { Resource reduction } \\
\text { targets }\end{array}$ & $\begin{array}{l}\text { Nox and Sox } \\
\text { emissions } \\
\text { reduction }\end{array}$ & $\begin{array}{l}\text { Equator } \\
\text { principles }\end{array}$ & $\begin{array}{l}\text { Policy career } \\
\text { development }\end{array}$ & $\begin{array}{l}\text { Fundamental } \\
\text { human rights } \\
\text { ILO UN }\end{array}$ & $\begin{array}{l}\text { Crisis } \\
\text { management } \\
\text { systems }\end{array}$ & $\begin{array}{l}\text { Quality mgt } \\
\text { systems }\end{array}$ \\
\hline $\begin{array}{l}\text { Environment } \\
\text { management team }\end{array}$ & $\begin{array}{l}\text { Voc or } \\
\text { particulate } \\
\text { matter } \\
\text { emissions }\end{array}$ & $\begin{array}{l}\text { Equator } \\
\text { principles or } \\
\text { environmental } \\
\text { projects }\end{array}$ & $\begin{array}{l}\text { Policy } \\
\text { diversity and } \\
\text { opportunity }\end{array}$ & $\begin{array}{l}\text { Human rights } \\
\text { contractor }\end{array}$ & $\begin{array}{l}\text { Anti } \\
\text { competition } \\
\text { controversies }\end{array}$ & ISO 9000 \\
\hline $\begin{array}{l}\text { Environment } \\
\text { management } \\
\text { training }\end{array}$ & $\begin{array}{l}\text { Voc emissions } \\
\text { reduction }\end{array}$ & $\begin{array}{l}\text { Environmental } \\
\text { project } \\
\text { financing }\end{array}$ & $\begin{array}{l}\text { Employees } \\
\text { health and } \\
\text { safety team }\end{array}$ & $\begin{array}{l}\text { Ethical trading } \\
\text { initiative ETI }\end{array}$ & & $\begin{array}{l}\text { Six sigma and } \\
\text { quality mgt } \\
\text { systems }\end{array}$ \\
\hline $\begin{array}{l}\text { Environmental } \\
\text { materials sourcing }\end{array}$ & $\begin{array}{l}\text { Particulate } \\
\text { matter } \\
\text { emission } \\
\text { reduction }\end{array}$ & Nuclear & $\begin{array}{l}\text { Health and } \\
\text { safety training }\end{array}$ & $\begin{array}{l}\text { Human rights } \\
\text { breaches } \\
\text { contractor }\end{array}$ & & $\begin{array}{l}\text { Product access } \\
\text { low price }\end{array}$ \\
\hline $\begin{array}{l}\text { Toxic chemicals } \\
\text { reduction }\end{array}$ & $\begin{array}{l}\text { Waste } \\
\text { reduction total }\end{array}$ & Labeled wood & $\begin{array}{l}\text { Supply chain } \\
\text { health and } \\
\text { safety training }\end{array}$ & & & $\begin{array}{l}\text { Healthy food or } \\
\text { products }\end{array}$ \\
\hline $\begin{array}{l}\text { Renewable energy } \\
\text { use }\end{array}$ & $\begin{array}{l}\text { e-Waste } \\
\text { reduction }\end{array}$ & $\begin{array}{l}\text { Organic } \\
\text { products } \\
\text { initiatives }\end{array}$ & $\begin{array}{l}\text { Employees } \\
\text { health and } \\
\text { safety OHSAS } \\
18001\end{array}$ & & & $\begin{array}{l}\text { Embryonic stem } \\
\text { cell research }\end{array}$ \\
\hline Green buildings & $\begin{array}{l}\text { Environmental } \\
\text { restoration }\end{array}$ & Product impact & Flexible & & & Retailing \\
\hline
\end{tabular}


initiatives

minimization

working hours

responsibility

Staff

Environmental supply chain

management

Environmental

supply chain

monitoring

transportation

impact

Take-back and

initiatives

Environmental Product

expenditures

investment

environmental

responsible use

Employee

fatalities

HIV-AIDS

GMO products

program

Agrochemical

products

Internal

promotion

Agrochemical Management

$5 \%$ revenue training

Animal testing Supplier ESG

in the last $12 \mathrm{fy}$ training

Wages

working

Animal testing

cosmetics

condition

controversies

Animal testing

reduction

Renewable

clean energy

products

Water

technologies

Sustainable

building

products alcohol

gambling

tobacco

armaments

Obesity risk

Cluster bombs

Antipersonal

landmines

Consumer

complaints

Customer

controversies

Responsible marketing

controversies

Product recall 
Table 4

Descriptive analysis

\begin{tabular}{|c|c|c|c|}
\hline Variable & Obs & Mean & Std. Dev. \\
\hline CSR & 13178 & 28.2536 & 17.98319 \\
\hline BODSIZE & 13178 & 10.89833 & 3.562284 \\
\hline INBODMEMBERS & 13178 & 63.28263 & 26.43705 \\
\hline FMLEBOARD & 13178 & 11.76378 & 11.02402 \\
\hline CEODUALITY & 13178 & 0.2987013 & 0.457706 \\
\hline CSRCOMMIT & 13178 & 0.5868459 & 0.4924187 \\
\hline SIZE & 13178 & 9.64261 & 1.477543 \\
\hline ROA & 13178 & 6.44361 & 8.447218 \\
\hline LEVERAGE & 13178 & 1.28872 & 21.70911 \\
\hline CAPITALINTENSITY & 13178 & 6.306013 & 5.734303 \\
\hline Basic Materials & 13178 & 0.1404614 & 0.3474783 \\
\hline Consumer cyclicals & 13178 & 0.188496 & 0.3911226 \\
\hline $\begin{array}{c}\text { Consumer Non- } \\
\text { Cyclicals }\end{array}$ & 13178 & 0.0984975 & 0.2979974 \\
\hline Energy & 13178 & 0.0996358 & 0.2995251 \\
\hline Healthcare & 13178 & 0.0776294 & 0.2675976 \\
\hline Industrials & 13178 & 0.2136895 & 0.4099257 \\
\hline Technology & 13178 & 0.0783123 & 0.2686727 \\
\hline $\begin{array}{c}\text { Telecommunication } \\
\text { services }\end{array}$ & 13178 & 0.0395356 & 0.1948728 \\
\hline Utilities & 13178 & 0.0637426 & 0.2443031 \\
\hline
\end{tabular}


Table 5

Multivariate analysis results

\begin{tabular}{|c|c|c|c|c|c|}
\hline CSR & $\begin{array}{l}\text { MODEL } 1 \\
\text { Coef. } P>|t|\end{array}$ & $\begin{array}{l}\text { MODEL } 2 \\
\text { Coef. } P>|t|\end{array}$ & $\begin{array}{l}\text { MODEL 3 } \\
\text { Coef. } P>|t|\end{array}$ & $\begin{array}{l}\text { MODEL } 4 \\
\text { Coef. } P>|t|\end{array}$ & $\begin{array}{l}\text { MODEL } 5 \\
\text { Coef. } P>|t|\end{array}$ \\
\hline BODSIZE & $\begin{array}{c}0.2169868 * * * \\
(0.0335604)\end{array}$ & & & & \\
\hline INBODMEMBERS & & $\begin{array}{c}-0.0139185^{* *} \\
(0.0061487)\end{array}$ & & & \\
\hline FMLEBOARD & & & $\begin{array}{c}0.0339063 * * * \\
(0.0099131)\end{array}$ & & \\
\hline CEODUALITY & & & & $\begin{array}{c}0.5852023 * * * \\
(0.2034985)\end{array}$ & \\
\hline CSRCOMMIT & & & & & $\begin{array}{l}5.878486 * * * \\
(0.18197519\end{array}$ \\
\hline SIZE & $\begin{array}{c}0.0862391 * * \\
(0.0427484)\end{array}$ & $\begin{array}{c}0.0599078 \\
(0.0466991)\end{array}$ & $\begin{array}{c}0.0938555^{* *} \\
(0.0427647)\end{array}$ & $\begin{array}{c}0.0851251^{* *} \\
(0.0428215)\end{array}$ & $\begin{array}{c}0.0877081^{* * *} \\
(.0414824)\end{array}$ \\
\hline ROA & $\begin{array}{c}-0.0164225^{*} \\
(0.0097265)\end{array}$ & $\begin{array}{l}-0.0155546 \\
(0.0107125)\end{array}$ & $\begin{array}{l}-0.0152843 \\
(0.0096525)\end{array}$ & $\begin{array}{l}-0.017145^{*} \\
(0.009741)\end{array}$ & $\begin{array}{l}-0.0128036 \\
(.0094187)\end{array}$ \\
\hline LEVERAGE & $\begin{array}{c}0.0000125 \\
(0.0000248)\end{array}$ & $\begin{array}{c}0.0000208 \\
(0.0000254)\end{array}$ & $\begin{array}{c}-4.92 \mathrm{e}-07 \\
(0.0000249)\end{array}$ & $\begin{array}{c}0.0000113 \\
(0.0000249)\end{array}$ & $\begin{array}{c}0.000013 \\
(0.0000241)\end{array}$ \\
\hline CAPITALINTENSITY & $\begin{array}{l}-0.0055852 \\
(0.0172711)\end{array}$ & $\begin{array}{c}0.0102097 \\
(0.0186409)\end{array}$ & $\begin{array}{c}-0.00179 \\
(0.0171854)\end{array}$ & $\begin{array}{l}-0.003505 \\
(0.0172971)\end{array}$ & $\begin{array}{l}-0.0057703 \\
(0.0167102)\end{array}$ \\
\hline Basic Materials & $\begin{array}{c}3.952527 * * \\
(1.85382)\end{array}$ & $\begin{array}{c}2.861273 \\
(1.960619)\end{array}$ & $\begin{array}{c}4.227316^{* *} \\
(1.880081)\end{array}$ & $\begin{array}{c}3.998713 * * \\
(1.881582)\end{array}$ & $\begin{array}{l}2.852793^{*} \\
(1.712115)\end{array}$ \\
\hline Consumer cyclicals & $\begin{array}{c}-0.0995523 \\
(1.77393)\end{array}$ & $\begin{array}{l}-0.4519622 \\
(1.867276)\end{array}$ & $\begin{array}{l}0.1157553 \\
(1.798513)\end{array}$ & $\begin{array}{l}0.0783055 \\
(1.801463)\end{array}$ & $\begin{array}{r}-0.1183876 \\
(1.638888)\end{array}$ \\
\hline $\begin{array}{l}\text { Consumer Non- } \\
\text { Cyclicals }\end{array}$ & $\begin{array}{c}6.094823 * * * \\
(1.984853)\end{array}$ & $\begin{array}{c}5.776986 * * * \\
(2.091798)\end{array}$ & $\begin{array}{c}6.339149 * * * \\
(2.011927)\end{array}$ & $\begin{array}{c}6.428756 * * * \\
(2.015104)\end{array}$ & $\begin{array}{c}5.659458 * * * \\
(1.833412)\end{array}$ \\
\hline Energy & $\begin{array}{r}-0.0715523 \\
(1.976856)\end{array}$ & $\begin{array}{l}-0.403273 \\
(2.06554)\end{array}$ & $\begin{array}{l}0.2176056 \\
(2.004735)\end{array}$ & $\begin{array}{l}0.0462844 \\
(2.007474)\end{array}$ & $\begin{array}{l}-0.4917067 \\
(1.826984)\end{array}$ \\
\hline Industrials & $\begin{array}{c}3.304227^{*} \\
(1.90902)\end{array}$ & $\begin{array}{l}3.170937^{*} \\
(1.845038)\end{array}$ & $\begin{array}{l}3.730622 * * \\
(1.773983)\end{array}$ & $\begin{array}{l}3.617075 * * \\
(1.776633)\end{array}$ & $\begin{array}{l}3.099389^{*} \\
(1.616403)\end{array}$ \\
\hline Technology & $\begin{array}{l}0.8814618 \\
(2.082941)\end{array}$ & $\begin{array}{c}1.502662 \\
(2.194966)\end{array}$ & $\begin{array}{c}0.9555619 \\
(2.111962)\end{array}$ & $\begin{array}{l}0.8092371 \\
(2.115338)\end{array}$ & $\begin{array}{c}1.140682 \\
(1.924884)\end{array}$ \\
\hline $\begin{array}{l}\text { Telecommunication } \\
\text { services }\end{array}$ & $\begin{array}{l}1.744045 \\
(2.560848)\end{array}$ & $\begin{array}{c}1.662867 \\
(2.668485)\end{array}$ & $\begin{array}{c}2.201852 \\
(2.595326)\end{array}$ & $\begin{array}{c}2.248233 \\
(2.599799)\end{array}$ & $\begin{array}{c}2.012671 \\
(2.365321)\end{array}$ \\
\hline Utilities & $\begin{array}{c}5.781166^{* *} \\
(2.240885)\end{array}$ & $\begin{array}{c}5.964641^{* *} \\
(2.344962)\end{array}$ & $\begin{array}{c}6.286166^{* * * *} \\
(2.270838)\end{array}$ & $\begin{array}{c}6.26766^{* * *} \\
(2.274632)\end{array}$ & $\begin{array}{l}5.195879 * * \\
(2.069602)\end{array}$ \\
\hline _cons & $\begin{array}{c}26.79453 * * * \\
(1.586536)\end{array}$ & $\begin{array}{c}30.56364 * * * \\
(1.722407)\end{array}$ & $\begin{array}{c}28.1683 * * * \\
(1.583321)\end{array}$ & $\begin{array}{c}28.74224 * * * \\
(1.576331)\end{array}$ & $\begin{array}{r}25.5068 * * * \\
(1.444898)\end{array}$ \\
\hline $\mathrm{N}$ & 13178 & 13178 & 13178 & 13178 & 13178 \\
\hline sigma_u & $16.47686^{* * *}$ & $16.65614 * * *$ & $16.71272 * * *$ & $16.73866 * * *$ & $15.2074 * * *$ \\
\hline sigma_e & $5.773662 * * *$ & $5.617259 * * *$ & $5.719102 * * *$ & $5.784109 * * *$ & $5.600827 * * *$ \\
\hline & 0.8906406 & 0.8978784 & 0.8951741 & 0.8933298 & 0.8805592 \\
\hline
\end{tabular}

